\title{
The Coalition Party And The Performance Of Government

\author{
(Evaluation Of The Performance Of Government And The Challenges Forward)
}

\author{
Panca Setyo Prihatin \\ Doctoral Program Students \\ Institute Of Governance In The Country \\ Lecture at Islamic University Of Riau
}

\begin{abstract}
This paper discusses the relationship of the coalition of political parties and the performance of the Government, with its main focus was how to build a strong coalition for the sake of the realization of the legitimate Government, strong, trustworthy and capable of carrying out the task. Further discuss the overview of the product performance of the Government, and how to build in the future.

Keywords: political parties, the performance of the Government, the Coalition
\end{abstract}

\section{INTRODUCTION}

The year 2014 for Indonesia is often referred to as the "year of politics", this is because the process happens at this year's national leadership cycle of five years. This process begins with the stages of the general election (Election) of the legislature, namely the election of the members of the regional representative Council (DPD-RI) and the House of Representatives Rakyat (DPR-RI) at the national level/Center, as well as Regional people's Delegation Council (DPRD) Province and district/city.

Next year it will also be carried out Presidential and vice presidential (presidential election), followed by the appointment of a cabinet by the President.

The dynamics of politics in Indonesia "in politics" is very dynamic, is characterized by:

1. The dynamics of the political party (political party), a political party as a political force with an interest in the five-yearly cycle, where the party concerned the territorial elections (DPR-RI/DPRD) and also as the sole determinant in the nomination of President and Vice President. So that it often happens through political maneuvers cadres the party leadership, which was was of course working to its fullest for winning the competition in the elections as well as presidential elections. This happens not only at the central level but also arrived at the area.

2. The dynamics of the Individual's political Actors, the actors individually attempting to lift the "self-image" to be worthy of support given and entrusted to occupy political office.
3. The dynamics of the community, the present society most of the attention anywhere are always discussing, even involved in the election and the presidential election, it is seen in everyday conversation that occurs in the middle of the community.

The dynamics of politics and even the national leadership cycle is aimed to form a Government that is legitimate, strong, trustworthy and able to carry the national tasks in the development of the nation and the Country to achieve goals to realize a fair and prosperous society.

How to form a Government, is not something that is easy, is linked to a variety of factors that are very complex. In connection with this emphasis on how a political party/coalition can be instrumental in creating a Government that is legitimate, strong, trustworthy and capable of carrying out the task.

The formation of the Government (Executive and Legislative) in Indonesia is currently (since 1999) is related to the mechanism of the party system and elections, as well as the presidential elections.

Indonesia has a multi-party election, and since the postwar new order 1999, no political party has the votes or seats in the DPR-RI more than 50\%, was seen in the following table;

Table 1

Tally the votes and seats seven major parties In the 2004 Legislative Elections [1]

\begin{tabular}{|l|c|c|c|c|}
\hline $\begin{array}{l}\text { Political } \\
\text { Parties }\end{array}$ & Vote & Percentage & Position & Percentage \\
\hline Golkar & 24.480 .757 & 21,58 & 128 & 23,27 \\
\hline PDIP & 21.026 .629 & 18,53 & 109 & 19,81 \\
\hline PKB & 11.989 .564 & 10,57 & 52 & 9,45 \\
\hline PPP & 9.248 .764 & 8,15 & 58 & 10,54 \\
\hline P Demokrat & 8.455 .225 & 7,45 & 57 & 10,36 \\
\hline PKS & 8.325 .020 & 7,34 & 45 & 8,18 \\
\hline PAN & 7.303 .324 & 6,44 & 25 & 4,54 \\
\hline
\end{tabular}

Source: Budiardjo, Miriam (2008:454) 
Table 2

The acquisition of seats and percentage of party In the 2009 Legislative Election

\begin{tabular}{|c|c|c|}
\hline $\begin{array}{c}\text { Political } \\
\text { Parties }\end{array}$ & Position & Percentage \\
\hline P Demokrat & 148 & 26,43 \\
\hline P Golkar & 108 & 19,29 \\
\hline PDIP & 93 & 16.61 \\
\hline PKS & 59 & 10,54 \\
\hline PAN & 42 & 7,50 \\
\hline PPP & 39 & 6,96 \\
\hline Gerindra & 30 & 5,36 \\
\hline PKB & 26 & 4,64 \\
\hline Hanura & 15 & 2,68 \\
\hline
\end{tabular}

Source: Electoral Commission, 2009

Table 3

The acquisition of seats and percentage of party In the Legislative elections of 2014

\begin{tabular}{|c|c|c|}
\hline Partai & Chair & Percentage \\
\hline PDIP & 109 & 18,95 \\
\hline P Golkar & 91 & 14,75 \\
\hline Gerindra & 73 & 11,81 \\
\hline Demokrat & 61 & 10,19 \\
\hline PAN & 49 & 7,59 \\
\hline PKB & 47 & 7,04 \\
\hline PKS & 40 & 6,79 \\
\hline PPP & 39 & 6,53 \\
\hline Nas Dem & 35 & 6,42 \\
\hline Hanura & 16 & 5,26 \\
\hline
\end{tabular}

Source: Electoral Commission, 2014

A third of the table above clearly visible that there is no domination of one Party against the other Party ultimately, this led to the necessity of there are coalitions of political parties/merge to fight for his interests in legislative/parliamentary or Governance/Executive. Both in the recruitment process and the term of the policy process in the Parliament, nor in terms of the formation of the Government (the experience of Indonesia since the year 1999).

This paper looks at how the relationship between the coalition parties with the performance of the Government with the coalition of the Centre focuses on how the effect on the process of legislative, Executive, and the relationship between the legislative and the Executive, which in the end effect on the performance of the Government. Further, examine how the challenges ahead (2014 presidential election and post-election).

\section{DISCUSION}

A. Party Politics, Party System, and the Electoral System

What is the real meaning of the party or of a political party, simply means the party is "gathering (party people) are seas, favors, and goal (especially in the political sphere). The term party or political party (political party) is similar to the understanding gained in a dictionary of Sociology of the party is one group with free affiliation, that concern all problem facing the country as a political institution. In terms of the above, the Assembly of the mash is passive, the origin of the get-together was enough.

In the context of a political party, in fact, not only the origin of the get-together but much more than that. The party is a gathering of people who are like-minded in political views that are then breathed and won his views.

Definition political party, according to Maurice Duverger was an organized group seeking political authority good through democratic elections or through revolution. When Duverger definition party as an organization that captured the authority election democratic and could pass another revolution with Sven Quenter the definition party is an organization that lowers its candidate captured the seat of Parliament one of the country's national election.

The main function of a political party is to retain power in order to realize the program programs compiled on the basis of a particular ideology. The way is to retain and capture the power is to participate in the elections.

And in general, the functions of political parties include:

a) Socialization is the process of the formation of political attitudes and political orientation of the members of the civil society. This process lasts a lifetime through formal and informal means of mobilizing through meetings, out and within the existing community. Socialization in the community there are two political education (dialogue) and political indoctrination (one way)

b) Political recruitment, a selection is the appointment of a person to perform a number of roles in the political system in General to the Government.

c) Political participation, the activities of the citizens of near was affecting the process of preparation and implementation of activities. In this case, it can support and oppose.

d) Integrators of interests, there are a number of different interests in society and each would like to accomplish in the importance and precedence, in this case, political parties serve to aggregation interests in society. Then in the political system of the party's existence then totality not needed because there are a desire and interest in religion.

e) Political communication, political parties serve to communicate the program, policy, derived from the aspirations of the Government and also of the community to the Government (with the language that is understood by the society). 
f) Control of the conflict, the party was present in the middle of the community, the party should become wirepuller and give a solution when a conflict in the middle of the community.

Matthiias Caton (2007) [2] the four main functions of the Centre put forward in modern democracies, namely:

a) To develop consistent policies and government programs (the interest articulation function).

b) To pick up demands from society and bundle them (the interest aggregation function).

c) To recruit, select and train people for positions in the government and the legislature.

d) To oversee and control the government.

The party system in which political parties become part of it is something practice and institutional phenomena which commonly found almost all over the country who called himself a democratic political system. The existence of this organization is so absolute conditio quano sin for the sustainability of the country's modern political system.

The Party System is the behavior patterns and interactions among a number of political parties. To distinguish between the political parties and the party system then obviously is that political parties are "organizations that aim to influence and get power made through elections". Whereas the system of Party is " interaction the parties to each other and their relationship with the political system as a whole". So is the political party Organization in the (internal organization) while the party system as its environment (external environmental).

There are at least two ways that can be done to analyze the party system; First, as units, party allocation as a unity separate from other units, by focusing on one party only (judging from the history, function or study) we can see the influence of the party in the party system. Second, view and discuss the interaction between some or a lot of unity. It is by looking at the dynamics of the relationships between political parties, by looking at a lot of parties and their interactions, we can get a better picture than the first way.

The party system is understood as the structure of the arrangement of the parties in one country (Dieter Nohlen and Elmar Wiensendahl), where the elements referred to are: the number of the party, the degree of the Party (the disunity), ideologis Relations or the degree of polarization, Interaction patterns, his relationship with the community, its position against the political system, the degree of institutional the party system.

Leo Agustino (2007) suggests that the party system is a mechanism of interactions between parties in a political system that is running. That is because the main goal of the party is to seek and retain power in order to realize the programs drawn up based on a particular ideology, then to realize these programs interact with one of the existing party with the other party in a system. At least we classically refer to the theory of Maurice Duverger [3], the party there are some systems which can be used in the realisation of the interactions between parties in a political system, namely: the one-party system (the one-party system), the two-party system (two-party system), as well as a multi-party system (party system).

The selection of an Electoral system is one of the decisions quality institutional and political system. Because the election system will generate logic-logic as a tool of political, administrative, bureaucratic, and went on growing and growing civil society within that system. Thus the selection of the electoral system into a work that is not easy and as simple as discourse many parties.

Miriam Budiardjo (2008) argued in political science known to the electoral system assortment with a wide variation, but generally revolve around two staple principle, namely:

a) Single-member constituency (electoral area one chooses one representative; usually called district system).

b) Multiple-member constituency (one electoral vote some representative; usually called balanced representation system/system proportional.

Presidential elections (presidential election) is part of the electoral system for selecting a President, Indonesia is currently using the presidential elections directly, where all citizens are legitimate by law can exercise his right to choose a spouse The President and Vice President directly.

According to Leo Agustino, within the framework of its President directly electoral system contained the meaning of substantial importance among these are:

a) Creation of equilibrium (balance) legitimacy at a time check and balances between the legislative and executive institutions

b) Accountability President elected directly to constituents voters (directly responsible to the people) that is expected to be able to create the conditions necessary for a legitimate Government

c) Exertion a stable Government because of the control and legitimacy.

In general, we know the two terms that are frequently used by countries whose conduct presidential elections directly, i.e:

a) Direct Popular Vote was the presidential election based on the votes of the voters at the national level.

b) The Electoral College is a way the selection of a presidential candidate with the most votes mechanisms at the level of representative based on the province or territory then under the national level for exalted, the strength of this system is if turnout is less than a majority then the weight of an electoral college will be able to correct the lack of legitimacy due to the least amount of voters. Weakness is allowing one candidate to win 
despite only winning in some votes the densely populated state. Due to the President's legitimacy is weak. This system also gives great weight to the States which in its population.

\section{B. The coalition party and the performance of Government}

In theory on the coalition of political parties, when grouped broadly speaking there are two groups, that is, a coalition that is not based upon considerations of policy (policy blind coalitions) and coalitions that are based on the destination preferences the policy will be realized (policybased coalitions).

The form first coalition emphasized the principle of size or the number of seats in the Parliament, a minimum winning coalition and the assumption of the party to goal "office seeking" (maximizing power). The form of this kind of coalition loyalty coalition participants guaranteed tough and difficult to predict.

While the second group Coalition stressed similarities in policy preferences, at least connected coalition (made up of the same parties in the scale of policy and abolish the partners that are not important), and assuming the coalition party, aim "policy of seeking", which embodies the policy of according the interests of the party. When such a coalition is formed, then the loyalty of participants Coalition will be formed, because it is bound by equality policy objectives.

Saiful Mujani (2003) suggested coalition party for a presidential candidate is required, given the small chance of a presidential candidate from a party got an absolute vote in elections. The Coalition helped reduce the uncertainty of who will win the presidential election later. This coalition was done on the basis of the consideration that the support for political parties is often closely tied to support for a presidential candidate from the party concerned. Moreover, in our presidential election system, a person nominated for President by a political party or political parties combined. Political parties at least help reduce difficulty levels predict the behavior of voters against the President's candidates who will compete later. [4]

In addition, political parties are political machine had the most systematic mass mobilization of resources. Therefore, the coalition of political between parties is expected to serve as a big political machine to mobilize the masses of voters nominated President. There are no socio-political organizations that have the capability of national mass mobilization of political parties.

A coalition of parties made possible by many factors, among them because of the similarities between the party platforms that would include them. The platform is included in issues of religion and economics. But, the coalition could also be built on the basis of pure political expediency, namely to obtain public office strategically and then break it down among fellow participants of the coalition.
Coalition politics as a strategy to build a political force which is engaged in common vision - mission to penetrate the ring of power is a reasonable effort made every political party. Because with so greater power would be more likely to be obtained and the victory more likely to be achieved. We can capture signals from the efforts of the coalition of the Centre-the center built yet completely departs from the motivation to defend the interests of the people. Supposedly when the Coalition is indeed for the people they do not need to wait for the results of legislative election by making the acquisition of sound as a consideration. Consideration of obtaining votes as the coalition base reflects the magnitude of the motivational power of reality that accompanies the political parties' policy-political parties. From the acquisition of sound, this is the "cake of power" handed out the portions adjusted with small gains big votes a political party. But if this is indeed the Coalition for the people does not need to make small gains big votes a political party as coalition considerations. If any political party is indeed the only interested parties defending the people naturally into consideration coalition party is the platform. Party-political party with the same platform will be easier synergize goals and ideals.

But this is not a political universe space where idealism can be melted with the rolling policy that really pro people. Most political parties through his characters prefer an in the grey area. Although on the surface still trying to show his true identity as an idealist. Whereas with the naked eye, in general, we can see how the pull-pull more pragmatism became their choice. As a result of political spaces completely create realities where "there is no eternal friend and there are no perennial opponents, only lasting interest".

The coalition as a political strategy is perfectly reasonable, and power itself is an inevitability in the political scene. Because of his political power to survive parallels with close to power in addition to the factors in support of the people. The Coalition is becoming very urgent when played correctly. In the sense of a coalition built not merely reflect the "political trademark cow" - more than that the coalition should be a joint endeavor of all components of the nation to settle all its obligations and complete the problems are whack This nation.

Associated with the party system are reinforced by data (table $1 \&$ table 2) there are two hypotheses that can be used as references in the investigation of the coalition party. First, many of the party system is rather difficult to produce the absolute winner of the election and the absolute. This, of course, complicates the political development of strong governance. Because no one else from the party election participants has the absolute sound, then each party claims to have the mass of each, so that the logic of coalitions between parties to build a strong Government is becoming very important. This hypothesis has the inclination that power lies with the Coalition itself. The ruling Government should be able to keep the coalition in his Cabinet in order that created the expected development and promised while campaigning. 
Second, that political power was awakened in the system lies in the multiparty legislature (DPR). This hypothesis was awakened refer to the first hypothesis. Because the Executive was not so in the exercise of government administration, the need to maintain political stability in the country is the legislative institution. Furthermore, this is caused because the Government does not have a strong enough base to form a solid Government. Agustino (2007).

John. J. Coleman (1999), posited the concept of a phenomenon of divided government and a unified government in different democracies. Divided government has an impact on the emergence of a wide range of public policy that is not responsive to the needs of the public and causes the pattern of ineffective policy. Otherwise unified government at both the level of State or local government/federal will give impact the governmental system more effective and to policies that are able to respond to the needs, wants, and demands the public. [5]

The Government (Executive) as institutions to formulate and implement decisions that are binding for all its citizens. According to the traditional interpretation of the Triassic Politika, just implement the policies which have been enacted by the legislature. The authority of the Executive Board today is much broader than just carry out the policy.

Executive power includes several fields, namely; administrative, legislative, judicial, security, and diplomatic. Of course the extensive coverage, this mechanism relies on the form of a system of Government that is in the by each State's personal religious beliefs.

Performance governance refers to the extent to which the product/how big the treetops by the Government based on field assignments.

\section{CONCLUSION}

In this case is how to build a stronger governance and democratic. The current political constellation in accordance with the results of the legislative elections, 2014 no party winning an absolute majority. This indicates a pattern of the coalition party is still the main alternative.

Maneuver political maneuvers of the political power, as the party and individual actors, are laden with the interests of their respective mutual seeks to dominate. Pattern formation of coalition the party issue and often occur in the coalition party shift it.

In regard to the framework of thought on previous sections associated with the current reality has become imperative that the coalition was formed to increase the performance of the Government.

The coalition parties are useful for strengthening the functions of the territorial executive performance, strengthening, harmonization of relationships to the Executive and legislative, that can manifest a better government performance. Moreover, it can be concluded that:

Coalition Party pattern effect on the performance of the Government, where the Government in forming a strong need to get support from the coalition was good on the territorial agencies and executive agencies.

Coalition Government should always work together in supporting policy directions government so that it can be realized as well.

Evaluation of the performance of the Government, very prominent is the ability to maintain economic stability, the rule of law enforcement (the eradication of corruption), and the structuring of Government, as well as creating a domestic security.

In the face of the challenges of the future must be supported by a harmonious Government legitimate, clean, powerful, and capable of achieving the objectives of the country.

Recommendations, in building a strong future government need for awareness of all parties especially Party Politics in order to put aside personal interest or the group in order to grab greater importance, namely the national interest. Co-operation/synergy between parties needs to continue to be built to progress the development of democracy.

\section{REFERENCE}

[1] Budiardjo, Miriam. 2008. Dasar-Dasar Ilmu Politik,ed.rev. Gramedia Pustaka Utama. Jakarta.

[2] Caton, Matthias. 2007. Effective Party Assistence: Stronger Parties for The Better Democracy. IDEA Int. Polycy Paper Nov. 2007.

[3] Agustino, Leo. 2007. Perihal Ilmu Politik. Graha Ilmu. Yogyakarta.

[4] Mujani, Saiful. 2003. Koalisi Partai Untuk Presiden. Tempo No.44/XXXII/Desember. Jakarta 